\title{
INITIAL EXPERIENCES COMPARING CT-GUIDED RADIOFREQUENCY AND MICROWAVE ABLATION IN THE TREATMENT OF RENAL CARCINOMA
}

\author{
LUKA NOVOSEL ${ }^{1}$, IVAN PEZELJ², IGOR TOMAŠKOVIĆ ${ }^{2}$ DIJANA ZADRAVEC ${ }^{1}$ \\ ${ }^{1}$ Department of Diagnostic and Interventional Radiology, Sestre milosrdnice University Hospital Center, \\ Zagreb, Croatia \\ ${ }^{2}$ Department of Urology, Sestre milosrdnice University Hospital Center, Zagreb, Croatia
}

\begin{abstract}
Percutaneous ablative techniques under imaging guidance have become a frequently used treatment method in the therapy of primary T1a or secondary renal tumours, especially in patients who were burdened with comorbidities and are not surgical candidates. Radiofrequency ablation with single or multiple electrodes has been the primary ablative technique used and the mainstay of percutaneous therapy for a long time but with the evolution of technologies, microwave ablation and cryoablation have emerged as possibly more effective methods of treatment. After the initial experience with CT-guided radiofrequency ablation for renal carcinoma treatment in 6 patients, we started using microwave ablation with the following 6 patients. Our results showed microwave ablation to have better results in achieving complete tumour ablation, while requiring shorter hospitalization time and better patient satisfaction. There have not been any major complications, while minor complications were more frequent with microwave ablation. Due to shorter procedure time patients treated with microwave ablation, we no longer used general anaesthesia but only local anaesthetic with conscious sedation.
\end{abstract}

KEY WORDS: renal carcinoma, computer tomography, ablation therapy, interventional radiology

\section{POČETNA ISKUSTVA U USPOREDBI CT-VOĐENE RADIOFREKVENTNE I MIKROVALNE ABLACIJE U TERAPIJI KARCINOMA BUBREGA}

\section{Sažetak}

Perkutane ablativne tehnike pod kontrolom slikovnih metoda su postale često korištena metoda u terapiji primarnih tumora bubrega T1a stadija ili sekundarnih bubrežnih tumora, ponajprije kod pacijenata koji zbog komorbiditeta nisu primarno kirurški kandidati. Radiofrekventna ablacija s jednom ili više elektroda je bila prva korištena ablativna metoda i dugo vremena glavna okosnica perkutane terapije, no s razvojem novih tehnologija, mikrovalna ablacija i krioablacija su se pojavile kao potencijalno učinkovitije opcije liječenja. Nakon početnih iskustava s CT-vođenom radiofrekventnom ablacijom karcinoma bubrega kod šest pacijenata, započeli smo koristiti mikrovalnu ablaciju kod idućih šest pacijenata. Naši rezultati su pokazali da s mikrovalnom ablacijom postižemo bolje rezultate u smislu potpune ablacije tumora uz kraće potrebno vrijeme hospitalizacije i veću razinu zadovoljstva pacijenata nakon zahvata. Nisu zabilježene veće komplikacije, dok su manje komplikacije bile učestalije nakon mikrovalne ablacije. Pacijenti tretirani mikrovalnom ablacijom nisu zahtijevali opću anesteziju zbog kraćeg vremena ablacije.

KLJUČNE RIJEČI: karcinom bubrega, kompjuterska tomografija, ablativna terapija, intervencijska radiologija 


\section{INTRODUCTION}

Renal cell carcinoma (RCC) accounts for 3\% of malignancies in adults and $80 \%-90 \%$ of malignant renal tumours (1). Improvement in quality and higher availability of abdominal imaging lead to more frequent early detection of small, lowgrade renal tumours. The detection of RCC has increased over the past decade and each year there are around 270000 cases worldwide (2). Incidentally detected renal masses are usually smaller and at an earlier stage than those tumours that present clinically with symptoms (3). It has been shown that $80 \%$ of these incidentalomas in the kidney are histologically RCC (4). Except in diagnostic imaging, improvements have been made in therapy options available to treat early RCC. Traditional treatment includes open radical nephrectomy, nephron-sparing open or laparoscopic partial nephrectomy and percutaneous thermal ablative methods. Due to the proven advantages such as shorter recovery times and preservation of renal function the less extensive therapies are on the raise, especially percutaneous thermal ablative techniques. Currently, there is general consensus that smaller renal tumours $(<4 \mathrm{~cm})$, should be treated with minimally invasive techniques to preserve renal function and avoid surgical removal of the entire kidney (5).

Multiple thermal ablative techniques are used to treat renal tumours. Considerable data is available for the traditionally used radiofrequency ablation (RFA) $(6,7)$ and less for the newer technique, microwave ablation (MWA) (8-10). Since MWA offers certain advantages over RFA, numerous centers are now turning to this method as their main option. These advantages include shorter working time with larger ablation volume, higher achieved intratumoral temperatures, less dependence on electrical conductivities of tissue and better effectiveness in cystic lesions $(11,12)$. However, there are still only a few comparative studies for these two techniques in renal tumours and there is still a lack of long-term effectiveness and survival data for MWA. Therefore, while introducing percutaneous CT-guided thermal ablation for renal carcinoma at our institution we investigated clinical and oncologic outcomes, patient satisfaction and complications of treatment between RFA and MWA and the purpose of our study is to present our short and mid-term follow-up results.

\section{MATERIALS AND METHODS}

All included patients were indicated for percutaneous thermal ablation by a multidisciplinary tumour board which included urologists, radiologists and oncologists. After the MDT meeting, the patients were seen by the consultant urologist and interventional radiologist and an explanation was provided to the patient about the possible treatment options and their advantages and risks. Patients were also informed about the need for long term CT or MRI follow-up that is required after this therapy option. Patients that accepted the treatment with percutaneous ablation were then included in the treatment protocol. Inclusion criteria for ablation in terms of size of the lesion was small T1a RCC, either primary, metastatic or patients with a new lesion after initial resection, with a maximum tumour diameter up to $4 \mathrm{~cm}$. If the patients had a new lesion biopsy was performed in order to determine the histology of the lesion. From January 2017 to April 201812 patients were treated, 6 with RFA and 6 with MWA. Mean age of the patients was 64 years \pm 12.9 . Indications for percutaneous ablation treatment were: advanced age or poor surgical candidate with a suspicious or confirmed solitary lesion in 8 patients, single kidney after contralateral nephrectomy in 2 patients, poor renal function in one patient, and association of other cancers in one patient.

Information was obtained that included age and sex, previous therapy or surgery, longest diameter of the lesion, pathologic type of tumour, location of the lesion, perioperative hospitalization period, procedure duration, type of anaesthesia, need for blood transfusion, complications, and pre-and postoperative serum creatinine and urea levels.

All patients underwent routine baseline laboratory investigations, including coagulation parameters (international normalised ratio [INR] $<1.5$ was required at the time of treatment and platelet count $>50000$ ), renal function tests (serum creatinine and urea measurement) and full blood count.

As advised by the international guidelines all patients had an abdominal computed tomography (CT) or magnetic resonance (MR) imaging performed at least 4 weeks prior to treatment. Six patients required biopsy prior to ablation to confirm the diagnosis. The biopsy was performed just before ablation in 5 patients and in a prior session 
in one patient. The diagnosis of RCC was confirmed by pathologic findings in 5 patients together with pathologic subtype of the tumour, while the biopsy showed inadequate tissue sample after one biopsy.

\section{CT-guided RFA and MWA procedure}

RFA was performed under general anaesthesia in all patients. The procedure was performed with the Olympus Celon radiofrequency device with bipolar internally cooled electrodes, using one to three $10-15 \mathrm{~cm}$ electrodes at once depending on the size of the lesion. Local anaesthesia was always used ( $1 \%$ Lidocaine). When needed biopsy was performed before ablation using a coaxial $16 \mathrm{G}$ semiautomatic system. The MWA procedure was performed under general anaesthesia in first two patients but then in the later 4 patients under moderate sedation and all received local anaesthesia (Lidocaine). The microwave unit from HS Amica is capable of producing $100 \mathrm{~W}$ of power at 2450 $\mathrm{MHz}$. The cool-tip needle antenna has a diameter of $1.9 \mathrm{~mm}$ (14 gauge) and a length of $10-20 \mathrm{~cm}$. The antenna was percutaneously inserted into the tumor and placed at the desired location under CT guidance. A power output of $60-100 \mathrm{~W}$ was applied from 2 to 5 minutes depending on the size of the lesion, always in one needle placement.

\section{Anaesthesia}

During the procedure all six patients undergoing radiofrequency ablation were treated under general anaesthesia, as were two initial patients treated with microwave ablation. The last 4 patients were performed using conscious sedation for pain management. Patients who undervent conscious sedation complained of mild to severe pain during the procedure, but it did not affect the procedure performance. They received $5 \mathrm{mg}$ of midazolam half an hour before the procedure orally and intravenous infusion of $100 \mathrm{mg}$ of ketoprofenum with $50 \mu \mathrm{g}$ of fentanyl was injected during the procedure at rare occasion, when needed. In the general anaesthesia group, anaesthesia was induced with $2 \mathrm{mg} / \mathrm{kg}$ of propofol and $0.2 \mathrm{mg} / \mathrm{kg}$ of cisatracurium besylate. After tracheal intubation, anaesthesia was maintained with sevoflurane (1.1-3.4 vol \%) with $\mathrm{O} 2$ (2 L/min). Volumecontrolled mechanical ventilation was performed with a tidal volume of $6-10 \mathrm{~mL} / \mathrm{kg}$.

\section{Follow-up}

The follow-up included routine postoperative physical examination, laboratory tests and a three-phase contrast-enhanced CT or dynamic MRI imaging at 1,4 and 12 months after treatment. Technique effectiveness was defined as the absence of enhancement of any residual areas of the lesion at a follow-up contrast-enhanced examination. Local recurrence was defined as the appearance of postcontrast enhancement in scattered, nodular, or eccentric pattern inside or around the ablation zone.

\section{RESULTS}

From January 2017 to April 2018, we performed image-guided percutaneous ablation of 12 renal tumours in 12 patients. Patient and tumour characteristics are summarized in Table 1.

There was no significant difference in patient age or mean tumour size in both patient groups. The mean age of patients was $64 \pm 12.9$. There were 7 male and 5 female patients. 8 patients were poor surgical candidates: two due to advanced age, and six due to comorbidities which included cerebrovascular and cardiopulmonary disease and impaired renal function. Two patients had long-term anticoagulation therapy included and were considered at risk of open surgery. Two patients were previously treated with nephrectomy and had suspected metastases on the contralateral side.

Operation time was significantly shorter in patients treated with microwave ablation compared to radiofrequency ablation, with average ablation procedure time lasting 2,48 minutes and 13,4 minutes in average, respectively for the two methods.

Due to shorter ablation times four patients treated with MWA were performed using conscious sedation. Even though they complained of significant procedural pain, the overall satisfaction after treatment was reported higher in these patients compared to the general anaesthesia group, mainly due to shorter hospitalization time ( 2,8 days vrs. 4,2 days) and shorter time needed to complete recovery and return to normal activities.

At follow up 5 out of 6 patients treated with RFA had complete ablation of tumour at 1 and 4-month follow-up, without evidence of residual 
tumour or local recurrence. One patient with a cystic $4 \mathrm{~cm}$ large tumour had evidence of possible residual tumour tissue with discrete postcontrast opacification and diffusion restriction on dynamic MRI imaging. All patients undergoing MWA showed to have complete ablation on follow-up imaging. Three patients had cystic lesions in the kidney, one treated with RF showed incomplete ablation and two treated with MWA showed no evidence of residual tumour at follow-up.

There was no significant change in renal function (creatinine levels) noted after the procedure in any of the patients.

There was more significant damage noted to the surrounding renal parenchyma in the MWA group on follow up imaging, but there was no evidence of any significant renal function deterioration in these patients, so this was considered as an adequate safety margin ablation zone. There were no major periprocedural complications noted after ablation. Minor complications were recorded in 8 out of 12 patients, and were more often present after MWA. Two out of six patients treated with MWA demonstrated microhaematuria in the first 24 hours after the procedure, which spontaneously resolved at one week follow up. This was observed in one patient after RFA. Patients reported higher pain levels in the first 8 hours after treatment when MWA was used. This was treated with analgesia and resolved within the first 24 hours. Patients that underwent general anaesthesia took a longer time to completely recover after treatment and in one patient complained of neck pain and broken tooth due to intubation.

Biopsy was performed in 5 patients prior to ablation. An adequate sample was taken and diagnosis of RCC was confirmed in these five patients. All other patients had previously histologically proven RCC or known malignancy that was previously operated.

There was no major haemorrhage in the present cohort of patients requiring blood transfusion, vascular embolization or surgery. There were four patients who developed self-limiting perirenal haematoma after renal RFA, which were present at the time of treatment completion.

The histological subtype of lesions was: clear cell carcinoma (9) and papillary carcinoma (2). The one renal tumour with inconclusive biopsy, mainly due to the small sample size, was treated and followed-up like other confirmed patients.
Eight of the twelve treated tumours were exofitic in location, and four were parenchymal, with no centrally located tumours. Distribution of the lesions was: 7 were in the mid-third of the kidney, 2 in the upper pole and 2 in the lower pole. There was no difference in procedure outcome depending on the location of the tumour. Microhaematuria was more often present in the centrally located lesions.

\section{DISCUSSION}

The increase of early detection of renal carcinoma, while it is still at an early stage, has led to new treatment options being included into guidelines for therapy (13). Two things lead to that, higher availability of early diagnostic imaging with computer tomography and magnetic resonance imaging and development of new technologies that allow minimally invasive procedures to be applied whenever possible. Although surgical resection, including radical or partial nephrectomy still presents the mainstay and golden standard of therapy in patients with renal carcinoma, multiple studies have pointed to possible significant advantages of percutaneous ablation compared to surgery $(14,15)$. Unfortunately evidence supporting percutaneous ablation in renal carcinoma is still based mostly on multiple single-arm observational studies and large case series with a few meta-analyses and smaller randomised controlled studies (16-18). This is mainly why ablative methods still have difficulties becoming a standard therapy option in some institutions. When we discuss the outcomes of a therapy there are two important goals percutaneous ablation techniques try to accomplish in order to be considered a method of choice in a certain subgroup of patients. The first one is cancer-free survival which needs to be equal or better than surgical resection and the second is reduction of complications with higher renal function preservation. The main technology used for percutaneous ablation has been, for a long period of time, radiofrequency ablation and therefore most of the published data on ablation in RCC are mainly about $\operatorname{RF}(19,20)$. However newer technologies, including microwave ablation and cryoablation have started to show certain advantages compared to radiofrequency ablation, according to the experimental and clinical data 
published. These include shorter procedure times with larger ablation volume, higher achieved intratumoral temperatures, less dependence on electrical conductivities of tissue and better effectiveness in cystic lesions. However there have not been many studies comparing the proposed differences in efficacy and complications between RF and MWA in RCC patients (21). We introduced percutaneous image guided ablation as a therapy option in our medical centre in 2017. We performed the ablation procedure in kidneys with both technologies, RF and MWA that were available to us, and decided to compare our initial short and midterm results treating these tumours with RFA and MWA. Even though the main limitation of our study is a statistically insufficient number of procedures and short follow up interval, we managed to make some initial conclusions from our data. The efficacy of both radiofrequency and microwave ablation was not significantly different in small renal masses, however as suggested in the literature, MWA showed better results in larger and cystic lesions, due to its ability to produce larger ablation volumes. It also showed its advantage in treating larger cystic lesions, because the liquid component of the lesion does not interfere with the effectiveness like in RF, but adds to it since the basis of microwave energy transfer is based on friction between water molecules. Our data also indicated that there was no significant difference in the complication rate between these two methods, even though minor haematuria was more often present after MWA treatment of parenchymal lesions compared to RFA. This is probably due to the fact that MWA achieves larger ablation zones and thus in parenchymal lesions, the heat might cause minor injuries to the collecting system. This was however not clinically significant since the haematuria spontaneously resolved in a few days. We also managed to significantly reduce the hospitalization period for patients after we started to perform MWA under local anaesthesia. We made the preoperative preparation and recovery shorter - the patients were discharged the first postprocedural day. This also resulted in greater patient satisfaction according to our data even though the procedure itself was reported to be significantly more painful when performed without general anaesthesia. The cost-effectiveness of percutaneous ablation procedures compared to surgical methods was demonstrated through multi- ple analyses. Castle et al. demonstrated clear 6-month cost benefit of RF ablation when compared to open or robot assisted partial nephrectomy on 163 patients with RCC (22). Clear benefits of these methods are that they can potentially be performed as outpatient day procedures, with less complications and with shorter recovery times and shorter need for absence from work. When performed by microwave ablation our hospitalization period reduced compared to RFA mainly because general anaesthesia was not needed and next day release was achieved more often. The price of the MWA electrode is however higher then RFA electrodes, but still remains cost effective compared to open surgery.

Percutaneous CT-guided thermal ablation is proving to be non-inferior to surgical methods in terms of oncological long term effectiveness, however with added value of having less complications and better renal function preservation, being minimally invasive and more cost-effective. This leads to more small renal masses being treated with ablative techniques. Microwave technology has the potential of replacing the standard radiofrequency ablation in the treatment of RCC due to its ability to produce larger ablation volumes in shorter working time.

\section{REFERENCES:}

1. Jemal A, Siegel R, Ward E, Murray T, Xu J, Thun MJ. Cancer statistics, 2007. CA Cancer J Clin. 2007;57(1):4366.

2. Office for National Statistics. Cancer Statistics Registrations: Registrations of Cancer Diagnosed in 2008, England. London: Office for National Statistics, National Statistics; 2010.

3. Pantuck AJ, Zisman A, Rauch MK, Belldegrun A. Incidental renal tumors. Urology. 2000;56:190-196.

4. Remzi M, Marberger M. Renal tumor biopsies for evaluation of small renal tumors: why, in whom, and how? Eur Urol. 2009;55:359-367.

5. Ljungberg B, Cowan NC, Hanbury DC. EAU guidelines on renal cell carcinoma: the 2010 update. Eur Urol. 2010;58:398-406.

6. Psutka SP, Feldman AS, McDougal WS, McGovern FJ, Mueller P, Gervais DA. Long-term oncologic outcomes after radiofrequency ablation for T1 renal cell carcinoma. Eur Urol. 2013;63(3):486-492.

7. Takaki H, Nakatsuka A, Uraki J, et al. Renal cell carcinoma: radiofrequency ablation with a multiple-electrode switching system - a phase II clinical study. Radiology. 2013;267(1):285-292. 
8. Liang P, Wang Y, Zhang D, Yu X, Gao Y, Ni X. Ultrasound guided percutaneous microwave ablation for small renal cancer: initial experience. J Urol. 2008;180(3):844-848;

9. Carrafiello G, Mangini M, Fontana F, et al. Single-antenna microwave ablation under contrast-enhanced ultrasound guidance for treatment of small renal cell carcinoma: preliminary experience. Cardiovasc Intervent Radiol. 2010;33(2):367-374.

10. Castle SM, Salas N, Leveillee RJ. Initial experience using microwave ablation therapy for renal tumor treatment: 18-month follow-up. Urology. 2011;77(4):792797.

11. Brace CL. Radiofrequency and microwave ablation of the liver, lung, kidney, and bone: what are the differences? Curr Probl Diagn Radiol.2009;38(3):135-143.

12. Yu J, Liang P, Yu X, Liu F, Chen L, Wang Y. A comparison of microwave ablation and bipolar radiofrequency ablation both with an internally cooled probe: results in ex vivo and in vivo porcine livers. Eur J Radiol. 2011;79(1):124-130.

13. Ljungberg B, Cowan NC, Hanbury DC. EAU guidelines on renal cell carcinoma: the 2010 update. Eur Urol. 2010;58:398-406.

14. Choueiri TK, Schutz FA, Hevelone ND, et al. Thermal ablation vs surgery for localized kidney cancer: a Surveillance, Epidemiology, and End Results (SEER) database analysis. Urology. 2011;78(1):93-98.

15. Takaki H, Yamakado K, Soga N, et al. Midterm results of radiofrequency ablation versus nephrectomy for T1a renal cell carcinoma. Jpn J Radiol. 2010;28(6):460-468.

16. Pantelidou M, Challacombe B, McGrath A et al. Percutaneous radiofrequency ablation versus robotic-assisted partial nephrectomy for the treatment of small re- nal cell carcinoma. Cardiovasc Intervent Radiol. 2016;39(11):1595-1603

17. Guan W, Bai J, Liu J et al. Microwave ablation versus partial nephrectomy for small renal tumors: intermediate-term results. J Surg Oncol. 2012;106(3):316-321

18. Chang X, Liu T, Zhang F et al. Radiofrequency ablation versus partial nephrectomy for clinical T1a renalcell carcinoma: long-term clinical and oncologic outcomes based on a propensity score analysis. J Endourol Endourol Soc. 2015;29(5):518-525

19. Zagoria RJ, Pettus JA, Rogers M, Werle DM, Childs D, Leyendecker JR. Long-term outcomes after percutaneous radiofrequency ablation for renal cell carcinoma. Urology. 2011; 77:1393-1397.

20. Tracy CR, Raman JD, Donnally C, Trimmer CK, Cadeddu JA. Durable oncologic outcomes after radiofrequency ablation: experience from treating 243 small renal masses over 7.5 years. Cancer. 2010;116:31353142.

21. Abboud SE, Patel T, Soriano S, Giesler J, Alvarado N, Kang P. Long-Term Clinical Outcomes Following Radiofrequency and Microwave Ablation of Renal Cell Carcinoma at a Single VA Medical Center. Curr Probl Diagn Radiol. 2018;47(2):98-102.

22. Castle SM, Gorbatiy V, Avallone MA, Eldefrawy A, Caulton DE, Leveillee RJ. Cost comparison of nephron-sparing treatments for cT1a renal masses. Urol Oncol. 2013;31(7):1327-1332.

Corresponding author: Luka Novosel, Department of Diagnostic and Interventional Radiology, Sestre milosrdnice University Hospital Center, Ilica 197, 10000 Zagreb, Croatia.e-mail: novosel0701@gmail.com 